\title{
Analysis of the Financing Effect of the New Third Board Listing Companies
}

\author{
Huamin Li, Dandan Zhang* \\ School of Business, Shaanxi Normal University \\ Xian, 710119, China
}

\begin{abstract}
The development of society is inseparable from capital. The growth of enterprises cannot be separated from funds. At present, the traditional financing model cannot meet the financing needs of high-risk and high-return of small and medium-sized enterprises, which seriously hinders the development of small and medium enterprises (SMEs). For the construction of China's multi-level capital market, the establishment and improvement of the new three-board market is an important part that cannot be ignored. At the same time, the development of the new three-board market is also an effective way to alleviate the financing difficulties in science and technology of SMEs. This paper explores the time background of financing difficulties and multi-level capital market construction for SMEs, sets up a research framework, combines theory with practice, analyzes and demonstrates the financing model effects of SMEs in the new third board, and systematically discusses the new three boards as multi-level capital. The components of the market can help boost the development of SMEs and provide a new way for SMEs' financing. However, the new third board market is still in the early stage of development, and there are still problems and deficiencies in the financing function. This paper proposes some countermeasures and suggestions based on the analysis of the status quo.
\end{abstract}

Keywords-New third board; Financing effect; Listed companies

\section{INTRODUCTION}

Compared with the large enterprises that have developed and grown, small and medium-sized enterprises have some inherent disadvantages. Due to the limited size of smes and relatively high uncertainty and high risk development characteristics, traditional financial channels can hardly provide adequate financial support for small and medium-sized enterprises. This paper analyzes the financing effect of the listed companies in the new third board and intends to achieve the following objectives:

First, it provides a realistic basis for the choice of financing channels for small and medium-sized enterprises. At present domestic national and regional otc market has just started, mostly small and medium-sized enterprises in their choice in the face of the market confusion, the choice of this confusion will undoubtedly increase the enterprise cost, is not conducive to the development of small and medium-sized enterprises. Therefore, this paper select has entered a new three board market trading stock transfer of enterprise as the object, collect their public disclosure of information and data, through empirical studies of the enterprise after entering the new three board concrete financing effect, the research conclusions can be used as a small and medium-sized enterprises to select the otc market.

Second, analyze the existing defects and deficiencies in the new third board market, and propose improvement suggestions and measures. Based on the research of the new three board market in our country, analysis of the defects in the existing system, puts forward some improvement Suggestions, for the new three board can better play to the role of the national overthe-counter market, for more small and mid-sized enterprise financing problem lay the foundation. We will foster more high-quality enterprises through the new third board market, so as to promote the development of high and new technology industries.

\section{RESEARCH REVIEWED}

The new third board market has not been developed in China for a long time, and there are not many scholars to study it, and most of the literature is published in the last three years.

According to the research content, the relevant research results are summarized.

The perspective of small and medium-sized enterprises in the new three board market positioning, think for small and medium-sized enterprises (smes) on the new three board can regulate the business operation mode, and enhance the capacity of corporate financing, and can be set up by means of equity incentive talents to share with shareholders' interests and promote enterprise long-term development (Zhang, 2011). Eith the new three board listed companies as samples, the selection of the ten measures of financial data, using factor analysis method, the sorting analysis of 90 listed companies, the new three board company should increase revenue growth rate, net profit growth rate, growth rate of net assets per share and basic earnings per share to increase new three board listed enterprise value (Guo, Xiong, 2012)

By comparing the three board markets in the United States, reviewed the development history and current situation of China's new third board market and proposed that the market is small and the liquidity is poor. Lack of green switchboard channel; Risk control problem of the new three board market in our country and puts forward developing countermeasures according to the research and analysis, including expanded step by step, the construction of a national over-the-counter market, 
introducing market-making system, unified market regulation and set up a rotating plate mechanism xiong (2013).

\section{ANALYSIS OF THE SITUATION}

Since January 2006, 17 set up since the opening of the new three board market, through two pilot, expansion, as of June 2015 new three board market has 2568 listed companies, listed companies each year basic showed a trend of increased year by year, the number is especially in 2012, 2013 and 2012, has been explosive growth. From the industry distribution, the new three board listed companies are widely distributed in the highend manufacturing industry, information technology service industry, cultural communication industry, scientific research and technology service industry and other emerging fields. Many listed enterprises are the leading enterprises in the subdivision industry, with strong innovation ability and good growth. As of June 12, 2015 manufacturing accounted for the largest, to meet the new three board listed companies, $57 \%$ of the total information transmission times, software and information technology services, accounted for $19.35 \%$, combined the two big industry accounts for about $80 \%$ of the total number of new three board listed companies, thus, the new three board listed companies are mostly science and technology or innovative enterprise, and these high-tech enterprises for research and development cost is higher, at present society less financing channels, the new three board certainly solved this kind of major issues of financing for smes, also further push China's economic development.

\section{A. Analysis of market liquidity of new third board.}

To investigate the liquidity of the new third board market, the volume of the new third board needs to be analyzed. In terms of overall volume, the volume of new third board has also increased with the increasing number of listed companies (see Table 1).

TABLE I STATISTICS TABLE OF NEW THREE BOARD ENTERPRISES LISTED

\begin{tabular}{|c|c|c|c|c|c|c|c|c|c|c|}
\hline Project & 2006 & 2007 & 2008 & 2009 & 2010 & 2011 & 2012 & 2013 & 2014 & 2015 \\
\hline Total listed number & 6 & 16 & 30 & 46 & 62 & 87 & 190 & 343 & 1565 & 2568 \\
\hline New list number & 6 & 10 & 14 & 16 & 16 & 25 & 103 & 153 & 1222 & 1003 \\
\hline
\end{tabular}

From the point of clinch a deal the pen number, clinch a deal in 2006, a total of 251 transactions, is calendar year since at least, clinch a deal the pen number peaked in 2015, to 1283654 , from the perspective of clinch a deal the number of shares in 2006 is the lowest, in 2009, clinch a deal the number of shares have reached a small peak, but fell back in 2010, it was not until 2012 beyond the 2009 figures, to 11, 4.55 million, and since 2013, was growing by leaps and bounds, to June 12, $2015,10.57292$ billion shares. In terms of volume, the figure is growing almost every year except for 2010, which was slightly lower than 2009.From the amount of the three data point of view, seems to deal with the listed company growth of market is driven, but from the perspective of the average number of split in 2012 to clinch a deal clinch a deal the pen number, number of shares of each enterprise and clinch a deal amount is minimum, almost, of course, this also with the number 2012 listed companies explosive growth, investors participation factors still exist certain hysteresis. After 2013, along with the national policy, financial system reform deepening, the new three board listed companies population explosion of growth, the average transaction price, clinch a deal the quantity also reaching a record high on average. In June 2014 - June 2015 clinch a deal the case can be found, clinch a deal the number up to 822 shares, share transfer.13 1254607, a total turnover of 10768497.8210768497 yuan, the average transaction price is 8.58 yuan (total turnover/total transfer of shares). From the perspective of the data of monthly, transfer trading companies has positive correlation with number of transactions, turnover rate is as high as 10.7\% in April 2015, march and April 2015 years or more trading, and also is obviously positive correlation between trading volume and turnover(see Table 2). 
TABLE II NEW THREE BOARD TRANSACTION DATA (PERIOD UNITS: 10000 Shares; 10000 YUAN)

\begin{tabular}{|c|c|c|c|c|}
\hline Year & $\begin{array}{c}\text { Listed } \\
\text { enterprise }\end{array}$ & $\begin{array}{c}\text { Deal } \\
\text { number }\end{array}$ & Transaction number & Transactions number \\
\hline 2006 & 6 & 251 & 1592.63 & 8340.71 \\
\hline 2007 & 16 & 521 & 4420.15 & 23156.63 \\
\hline 2008 & 30 & 484 & 5407.86 & 29527.82 \\
\hline 2009 & 46 & 878 & 10735.76 & 48342.53 \\
\hline 2010 & 62 & 644 & 6951.29 & 41872.24 \\
\hline 2011 & 87 & 832 & 9562.76 & 56169.56 \\
\hline 2012 & 190 & 638 & 11455.51 & 58431.81 \\
\hline 2013 & 343 & 989 & 20242.52 & 81396.19 \\
\hline 2014 & 1,565 & 67,509 & 121387.38 & 667004.02 \\
\hline 2015 & 2,568 & $1,283,654$ & 1057292.05 & 9771726.85 \\
\hline
\end{tabular}

To sum up, although the trading volume of the new third board market is increasingly large, the overall market liquidity is relatively weak and the market activity level needs to be improved.

\section{B. Analysis of the directional capital increase of the new third board market.}

In the new three board listed companies property belongs to the Private company, can't a public stock offering, to the public are not able to raise, so only through Private Placement manner, the introduction of strategic investors. Therefore, the study of directional capital increase is an important index to analyze the role of new third board financing. The directional increase of enterprises in the new third board market is similar to the private placement of listed companies in the main board and secondary board market. Both refer to the issuance of shares to certain investors through non-public means. The new three boards are less restrictive on the behavior of targeted capital increase, as long as they comply with the provisions in the "Pilot Procedures for the Transfer of Stock Quotes from Unlisted Stock Co., Ltd. (Grant) of the Guanzhong Science and Technology Park Agency Co., Ltd.", which is in line with the private placement of listed companies. There are significant differences between the "Measures for the Management of Issuance of Securities by Listed Companies" and the "Detailed Rules for the Non-public Issuance of Stocks by Listed Companies."

TABLE III NEW THIRD BOARD LISTED ENTERPRISES (PERIOD UNITS:10000 SHARES; 10000 YUAN)

\begin{tabular}{|c|c|c|c|c|c|c|}
\hline Year & $\begin{array}{c}\text { Increased } \\
\text { number of times }\end{array}$ & $\begin{array}{l}\text { Additional issuance } \\
\text { shares }\end{array}$ & $\begin{array}{l}\text { Additional } \\
\text { number }\end{array}$ & $\begin{array}{l}\text { Expected } \\
\text { fundraising }\end{array}$ & $\begin{array}{l}\text { Average } \\
\text { additional } \\
\text { number }\end{array}$ & $\begin{array}{c}\text { Average } \\
\text { increase } \\
\text { money }\end{array}$ \\
\hline 2006 & 2 & 2 & 4250.00 & 11000.00 & 2125.00 & 5500.00 \\
\hline 2007 & 2 & 2 & 1754.64 & 8189.92 & 877.32 & 4094.96 \\
\hline 2008 & 7 & 6 & 6113.41 & 28388.83 & 873.34 & 4055.55 \\
\hline 2009 & 3 & 3 & 3344.00 & 13540.80 & 1114.67 & 4513.60 \\
\hline 2010 & 10 & 9 & 6751.95 & 59198.32 & 675.19 & 5919.83 \\
\hline 2011 & 22 & 21 & 18694.84 & 86739.93 & 849.77 & 3942.72 \\
\hline 2012 & 18 & 17 & 11384.92 & 46571.15 & 632.50 & 2587.29 \\
\hline 2013 & 90 & 79 & 55609.61 & 245716.11 & 617.88 & 2730.18 \\
\hline 2014 & 534 & 417 & 737319.71 & 2561792.71 & 1380.75 & 4797.36 \\
\hline 2015 & 1624 & 1224 & 1552084.13 & 6902204.39 & 955.72 & 4250.13 \\
\hline Total & 2312 & 1780 & 2397307.22 & 9963342.16 & 10102.14 & 42391.62 \\
\hline
\end{tabular}


Can be obtained from Table 3, since January 2007 Beijing times to complete the new three board market orientation for the first time since the capital increase, a total of 1224 companies increased the total 2312 directional, overall financing scale and amount of 23.97 billion shares and 99.63 billion yuan respectively, the average single directional scale and amount of capital increase to 101.0214 million shares and 423.9162 million yuan respectively.

From the perspective of the directional capital increase in the past years, the orientation of the new third board enterprises is more and more active. Therefore, although the orientation of the new third board is increasing rapidly, there is still lack of activity and attraction.

\section{New third board listed enterprise transfection analysis.}

Companies do not need through the rigorous process of IPO, but land new three board market directly, after being enterprise qualification conditions for listing, and the new three board market turned to the gem, small and medium-sized board or motherboard market, the listed before a rights issue and issuance, this behavior is refers to the new three board "board". In 2008, the new three board listed companies for a long time period after the new three board from card software, through the normal process of IPO in the small and medium-sized plate, opens up a new three board "switch board" chapter, which also contributed to the securities industry association released later on the share offer company pause, resume stock transfer to the relevant provisions of the notice, the new three board listed companies turn plate work also has the support of policy. After that until 2012, the new three board listed companies have in hokuriku pharmaceutical, century, such as 6 companies successfully completed the turn of the gem board by new three board market, there are 14 companies have entered the turn plate process. It can be said that the success of the rotating plate mechanism set up, making the new three board for those who want to further upgrade to senior level capital market of listed companies, the "incubator" and "reservoir" effect, believe that there will be more and more listed companies with the help of the rotating plate mechanism to complete the leapfrog development.

\section{CONCLUSIONS AND POLICY IMPLICATIONS}

New three board operations in nearly nine years, the scale expands unceasingly, for small and medium-sized enterprise financing platform, improve the corporate governance structure, improve company management ability, improve enterprise well-knownness, etc. have played a role. At present, the scope of the new third board has been expanded from the original four national high-tech zones to the whole country, and the regional problems of the new third board have been solved.as of June 12, 2015, has been have accumulated 2825 companies listed on the new three board market success, 11 of them are realized the turn of the small and medium-sized board or the growth enterprise market board, also means these tangible data also mean that the pilot work of the new third board market has achieved stage success. New three board market in support of the development of the small and medium-sized enterprises in China at the same time, also for the multi-level capital market in our country to build and perfect the compound under the regulatory system of national over-the-counter market laid a solid foundation and accumulated valuable experience.

Through the above we can see that the construction of the new three board and perfect for fiber trapped financing difficulties of small and medium-sized enterprises is of great significance, however, in this paper, analysis of data shows that the new three board financing effect still exist the following problems, to further improve:

Firstly the direct financing function of the new third board market is limited. Due to the new three board listed companies are listed companies, according to the related policy, the nature of the enterprise is not a public stock offering, so on the new three board to direct financing of listed companies, mainly have to rely on the directional capital this way, and in the implementation orientation before the capital increase, first of all should follow the corresponding process, such as deliberated by the board of directors of the company, access to the Chinese securities association also record-keeping letter of confirmation, accounting firm for verification, the securities industry association directional capital shares issued by registered letter, in the securities industry association subordinates clearing company deal with the formalities that register, and so on. Process also need to disclose the relevant information on time, also need to directional increase price, amount, objects, and confirmed in the form of directional increase and completes the industrial and commercial registration and issue the result report after the completion of registration, the complexity of the process, the financing efficiency is not high. The single financing method is also the main reason for the limited direct financing of the new third board.

Second, the liquidity in the new third board market is not optimistic. New three board market as an important part of the otc market in China, although has attracted 2825 listed companies to enter the market, the overall volume of synchronous growth, but the average volume is still in lower level, the key data is smaller than some regional otc market, with foreign mature capital markets in the same market gap is very big, can't and domestic main board, second board market liquidity. The financing efficiency is very important. The current liquidity of the new third board obviously cannot meet the needs of the enterprise, and the market allocation efficiency is too low.

Third, the new third board market is not perfect. In the new three board of listed companies, have many companies financial indicators in accordance with the higher level of capital market entry requirements, and these enterprises to turn to a higher level of capital market also is very strong. Although the new three board has had a turn of the gem, small and medium-sized plate mechanism, but in the past few years, only 11 companies successfully turning plate, a year on average less than two, the rotating plate efficiency is very low. Such a situation for those small and medium-sized enterprises, which are still in the swing between the direct sprint entry and the first opportunity to market, will undoubtedly increase the selection difficulty and the cost of selection. More worrying is that once the new three board financing efficiency and liquidity is not greatly improved, so after a period of time, the new three 
board market is bound to become small and medium-sized enterprises in the eyes of chicken ribs.

Our country is developing the construction of multi-level capital market system, the new three board market as the otc market in China capital market system, how to seize the policy and market opportunity, perfecting its system construction, to better serve small and medium-sized enterprises, is a problem that need to ponder. Facing the problems in the financing of the new third board market, I think the countermeasures to improve the financing effect are mainly from the following three aspects:

First, to reduce the barriers to entry for investors and to properly manage investors. On December 30, 2013 national small and medium-sized enterprise stock transfer of limited liability company for the national small and medium-sized enterprise stock transfer systematic appropriateness management regulations (try out) ("hereinafter referred to as the" appropriateness management rules") were modified, the purpose to better guide new three board investors appropriate management.

Second, speed up the introduction of market - making system. Market-making system, in which the driving mechanism of quotation, it is a kind of market trading system, by have a certain strength and credibility of legal act as marketmakers, continually provide investors with buying and selling price, and accept the price offered by the investors' business requirements, with its own funds and securities and the investors, thus to provide real-time and liquidity to the market, and implement a certain profit through the bid-ask spread. Market makers, by constantly providing two-way quotes to investors, trade their own funds and securities with investors.
Third, we should improve the system of rotating board and establish a green channel. As of February 2014, eight new third board listed companies were listed in small and medium sized board or gem board, and the companies were listed through normal IPO procedures. Who truly turning plate, it is to show the enterprise is no longer by publicly issuing new shares, and direct the new three board to a-share listed, listed and then through A rights issue or A rights issue new shares to increase equity raise funds. From this concept, there is no real sense in our country to achieve the listed companies through the switch board.

\section{REFERENCES}

[1] Anderson, Sweeney, Williams, Statistics for Business and Economics, 8th edition, American, Thomson Learning, 654-772.

[2] Bin Yang, the impact of the new third board on the financing of smes [J] China chain, 2013, (08), 51-57. (In Chinese)

[3] Yu Dai, Study on the countermeasures of cultivating new three board listed companies in hefei high-tech zone [D]. Hefei University of technology, 2012. (In Chinese)

[4] Yuxin Bai, research on otc market in China's multi-level capital market [D]. Tianjin normal university, 2012. (In Chinese)

[5] Bing Bai, tu yunjiao, China's otc market development research, based on the comparative analysis of otc markets at home and abroad, exploration of economic problems, 2012.04, 111-118. (In Chinese)

[6] Jingfeng Liu, research on the application of small and medium high-tech enterprises to private equity [D]. Jiangsu University of science and technology, 2011. (In Chinese).

[7] China securities regulatory commission (CSRC), business rules for the transfer of shares of small and medium-sized enterprises in China (trial), 2013.02.08. 